Rev. Ter. Ocup. Univ. São Paulo, v. 19, n. 2, p. i, maio/ago. 2008.

\title{
Editorial
}

\section{Núcleos de Apoio à Saúde da Família: integralidade e trabalho em equipe multiprofissional}

\author{
Elisabete Ferreira Mângia ${ }^{1}$, Selma Lancman ${ }^{1}$
}

A criação dos Núcleos de Apoio à Saúde da Família, em janeiro de 2008, se constitui como um passo importante para a consolidação da Estratégia de Saúde da Família e especialmente para o desenvolvimento e aprimoramento de um novo modelo de exercício do trabalho em equipe multiprofissional. Nele, as diretrizes da integralidade, qualidade, eqüidade e participação social devem ser concretizadas em ações coletivas centradas no desenvolvimento humano e na promoção da saúde, capazes de produzir saúde para além do marco individualista, assistencialista e medicalizante.

O projeto é ambicioso e pode parecer utópico quando avaliamos que o perfil formativo da maior parte dos profissionais de saúde ainda está muito distante desse horizonte e que muitos obstáculos serão encontrados no percurso

Os Núcleos visam fortalecer oito diretrizes na atenção à saúde: a interdisciplinaridade, a intersetorialidade, o território, a integralidade, o controle social, a educação permanente em saúde, a promoção da saúde e a humanização, atuando em oito áreas estratégicas: atividade física/práticas corporais; práticas integrativas e complementares; reabilitação; alimentação e nutrição; saúde mental; serviço social; saúde da criança, do adolescente e do jovem; saúde da mulher e assistência farmacêutica.

Os NASF deverão desenvolver ações junto às equipes de Saúde da Família de forma a apoiá-las em seu fazer cotidiano. Tais ações deverão ser planejadas e definidas em conjunto com as equipes e de acordo com as necessidades e realidade local. A Portaria GM n ${ }^{\circ} 154$, de 24 de Janeiro de 2008, (republicada em 04 de Março de 2008) define que o NASF

"deve ser constituído por equipes compostas por profissionais de diferentes áreas de conhecimento, para atuarem em parceria com os profissionais das Equipes Saúde da Família, compartilhando as práticas em saúde nos territórios sob responsabilidade das ESF no qual o NASF está cadastrado" (Brasil, 2008).

Serão duas as modalidades de Núcleos: o NASF 1 - composto por no mínimo cinco profissionais - Médico Acupunturista; Assistente Social; Profissional da Educação Física; Farmacêutico; Fisioterapeuta; Fonoaudiólogo; Médico Ginecologista; Médico Homeopata; Nutricionista; Médico Pediatra; Psicólogo; Médico Psiquiatra; e Terapeuta Ocupacional - e deve desenvolver ações junto à no mínimo 8 equipes de saúde da família. E o NASF 2, para municípios com densidade populacional abaixo de 10 habitantes por quilômetro quadrado, composto por no mínimo três profissionais de nível superior de ocupações não-coincidentes - Assistente Social; Profissional de Educação Física; Farmacêutico; Fisioterapeuta; Fonoaudiólogo; Nutricionista; Psicólogo; e Terapeuta Ocupacional - que deve desenvolver ações junto á no mínimo 3 equipes de saúde da família

As ações previstas pela Portaria são detalhadas para cada uma das oito áreas estratégicas. Dentre elas há destaque para necessidade das ações em saúde mental com a recomendação de que tais atividades devem integrar-se à rede de serviços evitando respostas simplificadas em procedimentos psiquiátricos e medicalizantes. Podemos salientar também as ações de reabilitação que abrangem as pessoas com deficiência com a priorização das ações de inclusão social.

A entrada dessas duas grandes áreas, saúde mental e reabilitação, nas atribuições dos NASF supre uma lacuna que inicialmente não havia sido prevista no campo da atenção básica e deveria ser priorizada, pois refere-se à grupos populacionais ainda insuficientemente acolhidos pelas ações das políticas públicas.

Para todas as profissões o desafio principal consiste em criar a possibilidade da atuação conjunta, integrada e intersetorial, que incorpore a participação dos usuários e traduza a nova concepção ampliada de saúde assumida pelo SUS. Ocorre que esse trabalho em equipe, para a maior parte dos profissionais, não é focado na graduação e deverá ser aprendido no cotidiano da produção das ações de saúde e na imersão no trabalho coletivo e no território onde a vida acontece.

Permeabilidade, inovação e plasticidade são alguns dos pré-requisitos para romper com a visão hierarquizada, corporativa e parcializada do trabalho em equipe, necessária e imprescindível para realizar esse projeto. Assim, podemos concluir que a responsabilidade sobre o sucesso dos NASF será de todos os atores envolvidos em sua construção.

\section{REFERÊNCIAS}

Brasil, Ministério da Saúde, PORTARIA No 154 DE 24 DE JANEIRO DE 2008, disponível em http://dtr2004.saude.gov.br/dab/nasf.php

\footnotetext{
1. Docentes do curso de Terapia Ocupacional do Departamento de Fisioterapia, Fonoaudiologia e Terapia Ocupacional da Faculdade de Medicina da Universidade de São Paulo, editoras da Revista de Terapia Ocupacional da USP.
} 